\title{
RANCANG BANGUN MOTOR - GENERATOR MAGNET PERMANEN JENIS NdFeB
}

\author{
Budhi Prasetyo ${ }^{1)}$, Teguh Harijono Mulud ${ }^{2)}$ \\ Teknik Konversi Energi, Politeknik Negeri Semarang, Indonesia 1
}

\begin{abstract}
Abstrak
Ketidaktersediaan energi listrik merupakan suatu masalah bagi masyarakat modern khususnya pengguna perangkat elektronik dengan konsumsi daya rendah. Dari permasalahan tersebut dibutuhkan suatu alat motor - generator magnet permanen jenis NdFeB untuk menghasilkan energi listrik. Sumber energi listrik berasal dari baterai 9 volt disusun seri untuk membangkitkan fluks inti besi dengan bantuan kumparan. Fluks inti besi motor impuls menghasilkan kutub magnet yang sejenis pada komponen rotor sehingga timbul gaya tolak menolak dan menyebabkan komponen rotor bergerak dan magnet rotor menginduksi kumparan stator. Metode tugas akhir yang dimulai dari tahapan pembuatan, perakitan dan pengujian seluruh komponen motor - generator. Pengujian menggunakan beban berupa lampu LED, tahanan keramik dan potensiometer. Tegangan keluaran generator yang diperoleh pada karakteristik beban nol ialah 8.83 VDC dan tegangan keluaran tertinggi sebesar 8.84 VDC dan arus

0.009 Ampere menggunakan beban potensiometer 18KOhm. Untuk mendapatkan daya keluaran yang lebih besar dengan melakukan pembuatan ulang komponen dengan ketelitian yang lebih tinggi, memvariasi jumlah magnet, merubah ukuran lilitan dan memperkecil lebar celah udara.
\end{abstract}

Kata kunci : motor - generator magnet permanen, daya rendah 


\section{PENDAHULUAN}

Perkembangan teknologi yang sangat pesat mendorong penggunaan energi yang sangat besar. Alat-alat hasil dari perkembangan teknologi tersebut sebagian besar adalah alat-alat portable yang mudah dibawa dan digunakan kapan saja dengan cadangan daya yang hanya cukup untuk beberapa jam saja. Sehingga ketika daya cadangan habis, alat tersebut tidak dapat digunakan lagi. Daya cadangan seperti battery dengan kapasitas yang besar mempunyai volume yang besar dan massa yang berat. Sehingga, daya cadangan dengan kapasitas besar tidak cocok sebagai pendamping alat portable.

Oleh karenanya, pembuatan charger atau pengisi daya portable sangat dibutuhkan sebagai pendamping alat-alat portable yang bisa digunakan kapan saja dan di mana saja dengan volume yang kecil dan massa yang ringan. Selain hal tersebut, pengisi daya portable bisa juga dipakai untuk sumber listrik bersih tanpa polusi untuk daerah-daerah terpencil yang belum teraliri listrik.

$$
\text { Pengisi daya portable ini dapat }
$$
dikategorikan sebagai pembangkit listrik dengan kapasitas daya rendah dengan memanfaatkan komponen berupa komponen generator fluks aksial magnet permanen dan motor impuls atau motor bedini. Generator fluks aksial dapat menghasilkan tegangan pada putaran rendah. Rancang bangun prototipe ini diawali dengan pembuatan komponen generator fluks aksial, motor impuls dan komponen pendukung lainnya serta proses pengolahan data pengujian berupa daya masukan dan daya keluaran generator ketika diberi beban.

Berdasarkan latar belakang tersebut dapat diketahui tujuan dari pembuatan alat ini guna (a) Merancang prototipe motor - generator fluks aksial magnet permanen jenis $\mathrm{NdFeB}$ (b) Menguji

trigger), rangkaian elektronik yang berfungsi sebagai saklar, inti besi dan sumber tegangan. Cara kerja alat karakteristik dari prototipe motor - generator fluks

aksial magnet permanen jenis $\mathrm{NdFeB}$ (c) Menganalisa kinerja motor - generator fluks aksial magnet permanen jenis $\mathrm{NdFeB}$

\section{TINJAUAN PUSTAKA}

\subsection{Generator}

\subsubsection{Rotor}

Rotor merupakan komponen generator yang dapat berputar. Komponen ini terdapat magnet permanen sebagai penghasil medan magnet yang kemudian diimbaskan ke komponen stator untuk menghasilkan tegangan induksi. Komponen rotor terdiri dari 2 buah piringan acrylic berbentuk lingkaran dan letaknya saling berhadapan dengan komponen stator. Pada komponen rotor terpasang sebuah bearing dan poros sehingga komponen rotor dapat berputar.

\subsubsection{Stator}

Stator merupakan komponen yang terdiri dari beberapa kumparan kawat (coil) email yang dilapisi dengan bahan isolator. Jumlah kumparan generator akan berpengaruh terhadap tegangan keluaran yang dihasilkan. Kumparan generator dapat dikonfigurasi menjadi susunan 1 fasa atau 3 fasa. Pada komponen stator dapat dipasang inti besi yang berfungsi untuk mempermudah jalannya fluks magnet pada komponen rotor

\subsection{Motor Impuls}

Motor impuls merupakan komponen yang dapat menghasilkan elektromagnet dengan bantuan kumparan. Komponen motor impuls merupakan pengembangan motor bedini yang digunakan sebagai penggerak mula komponen rotor. Komponen motor impuls terdiri dari kumparan (kumparan utama dan 
$\mathrm{e}=-N$

timbul tegangan induksi pada kumparan trigger kemudian tegangan induksi tersebut akan masuk ke kaki basis transistor TIP 31C $\left(\mathrm{T}_{1}\right.$ dan $\left.\mathrm{T}_{2}\right)$. Fungsi kedua transistor TIP 31C ialah memperkuat arus induksi/trigger sebelum masuk ke transistor utama $\left(T_{3}\right)$. Besarnya arus basis yang masuk ke transistor $T_{3}$ dapat diatur dengan memvariasikan nilai tahanan pada potensiometer. Pengaturan nilai arus basis menggunakan potensiometer akan berdampak terhadap tegangan yang masuk ke dalam kumparan utama guna membangkitkan elektromagnet.

\subsection{Magnet Permanen}

Magnet permanen yang digunakan dalam komponen generator ialah jenis magnet neodymiumiron-boron (NdFeB) grade 35 dan tidak memnbutuhkan arus eksitasi. Magnet $\mathrm{NdFeB}$ ini merupakan salah satu jenis magnet kuat daripada magnet jenis lain. Magnet jenis ini dibedakan berdasarkan tingkat atau grade. Magnet yang paling umum ditemukan ialah jenis grade N35 dan N52. Perbedaan kedua grade magnet tersebut ialah besar kuat medan magnet yang dihasilkan. Magnet grade N35 memiliki nilai kuat medan magnet yang lebih kecil dari grade N52 namun memiliki harga yang lebih terjangkau dari harga magnet grade N52

\section{$2.4 \quad$ Induksi Elektromagnet}

Pada generator terjadi elektromagnetik yang mengacu pada hokum Faraday dan Lenz. Pada hokum Faraday dijelaskan bahwa adanya perubahan fluks magnetik yang melingkupi suatu kumparan akan menimbulkan ggl induksi pada ujung-ujung kumparan, hal tersebut sesuai dengan persamaan $d \phi$

$d t$

Sedangkan hokum Lenz menjelaskan bahwa GGL induksi yang muncul berarah melawan perubahan fluks menyebabkan arus induksi menghasilkan medan magnet yang melawan perubahan fluks magnet yang menghasilkan arus induksi.

\section{METODE PENELITIAN}

Penelitian diawali dengan pembuatan dan perancangan komponen, perakitan komponen (motor, generator dan komponen pendukung). Diagram alir penelitian ditunjukkan pada gambar (1).

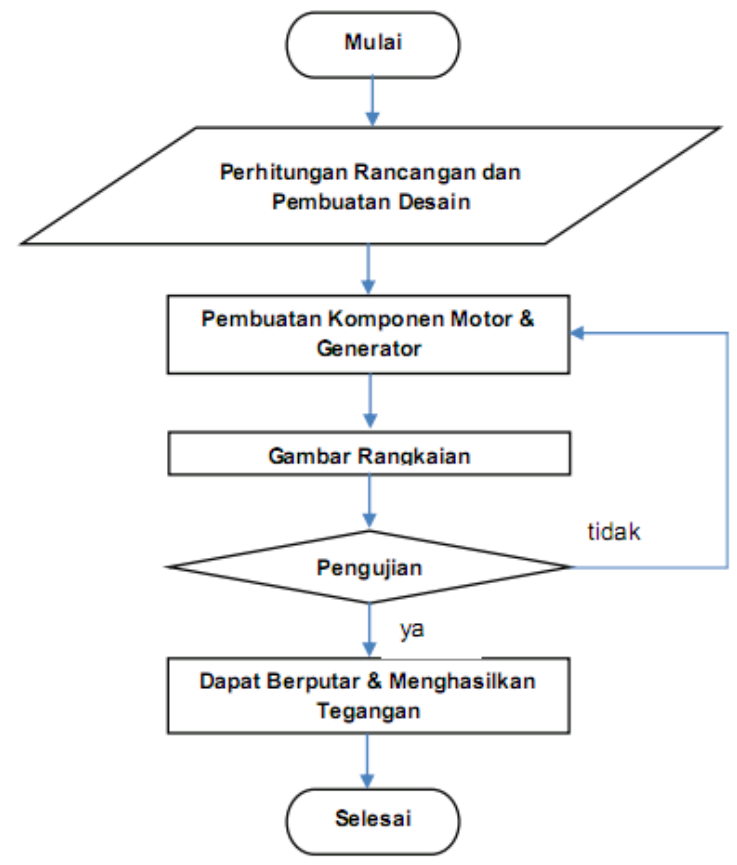

Gambar 1. Diagram Alir Penelitian

\subsection{Pembuatan Generator Fluks Aksial}

\subsubsection{Pembuatan Rotor}

Awal mula proses pembuatan komponen rotor dimulai dari pembuatan piringan rotor 
menggunakan acrylic, proses pembuatan lubang sebagai tempat peletakkan magnet bearing, pemasangan inti besi dan perakitan komponen rotor.

Pembuatan piringan rotor menggunakan papan acrylic bening dengan ketebalan $3 \mathrm{~mm}$. Diameter piringan rotor

\section{Tabel 1. Spesifikasi Komponen Rotor}

\begin{tabular}{l|l} 
Parameter & Besaran $(\mathbf{m m})$ \\
\hline Diameter Piringan Rotor & $400 \mathrm{~mm}$ \\
Lubang penempatan magnet stator & $30 \times 10 \mathrm{~mm}$ \\
Diameter lubang bearing & $40 \mathrm{~mm}$ \\
Diameter lubang rotor atas & $150 \mathrm{~mm}$
\end{tabular}

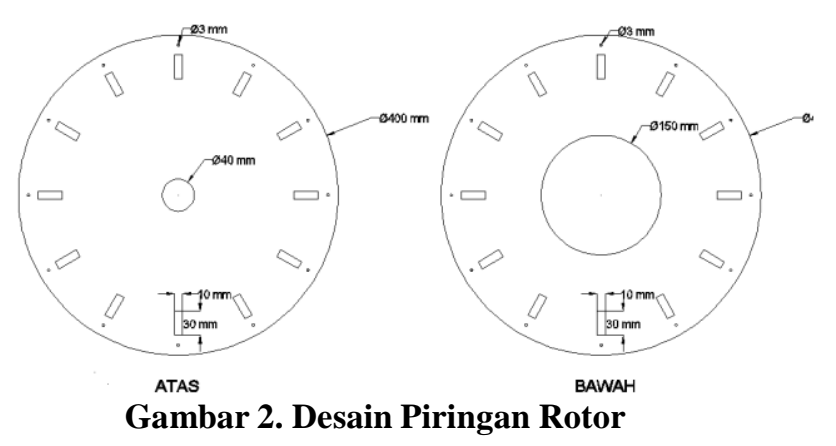

Magnet rotor digunakan sebagai komponen penggerak mula dari generator dengan memanfaatkan gaya tolak menolak antara magnet permanen dengan elektromagnet. Magnet rotor yang digunakan berjumlah 10 buah

\section{Tabel 2. Spesifikasi Komponen Magnet Rotor}

\begin{tabular}{l|l} 
Parameter & Besaran $(\mathbf{m m})$ \\
\hline Dimensi penempatan magnet & $65 \times 30 \mathrm{~mm}$ \\
(acrylic) & \\
Lubang penempatan magnet rotor & $20 \times 10 \mathrm{~mm}$ \\
Dimensi magnet terpasang & $20 \times 10 \times 7 \mathrm{~mm}$
\end{tabular}

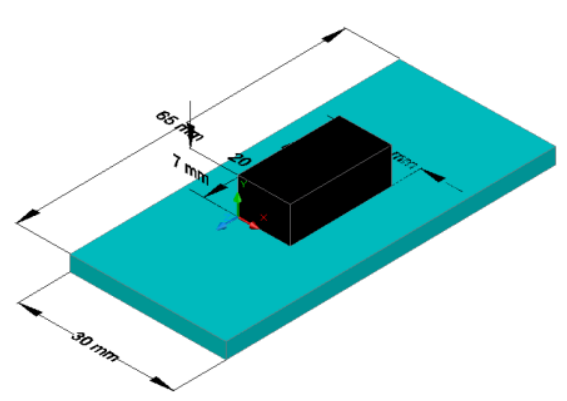

\section{Gambar 3. Desain Magnet Motor}

Inti besi memiliki fungsi untuk memperkuat medan magnet yang dihasilkan magnet permanen jenis NdFeB. Bahan inti besi terbuat dari plat galvanis dengan total inti besi yang digunakan ialah 12 buah

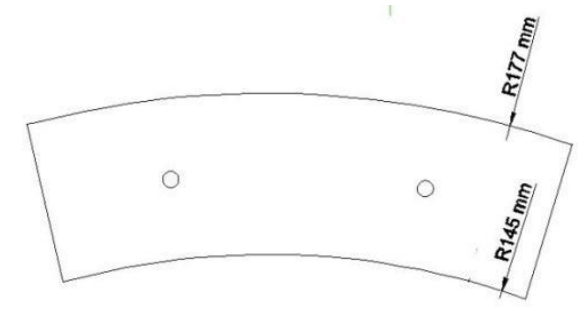

Gambar 4. Bentuk Inti Besi Rotor

Tabel 3. Spesifikasi Komponen Inti Besi

\begin{tabular}{l|l} 
Parameter & Besaran (mm) \\
\hline Ukuran inti besi luar & $177 \mathrm{~mm}$ \\
Ukuran inti besi dalam & $145 \mathrm{~mm}$ \\
Lubang pemasangan sekrup & $3 \mathrm{~mm}$
\end{tabular}

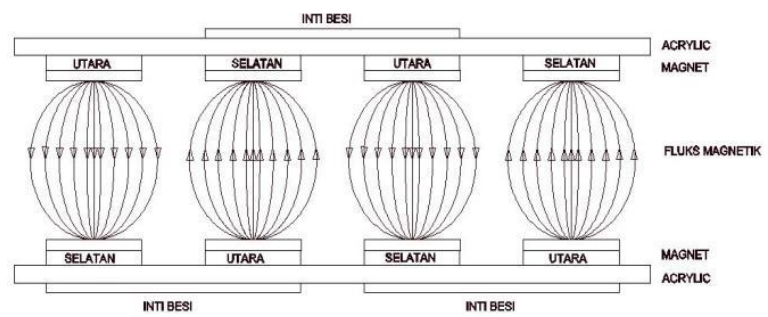

Gambar 5. Konfigurasi Pemasangan Magnet Generator 


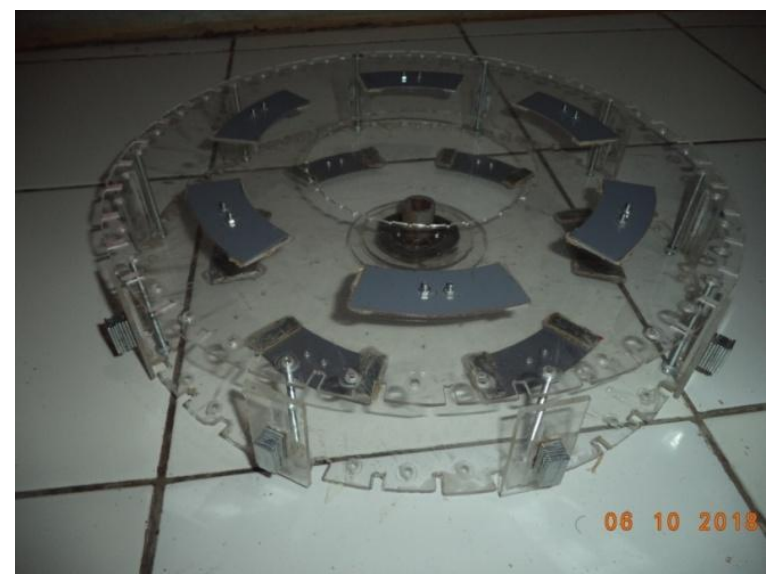

Gambar 6. Bentuk Komponen Rotor Akhir

\subsubsection{Komponen Stator}

Pembuatan awal komponen stator dimulai dari pembuatan piringan stator, pembuatan kumparan, penyusunan kumparan dan pemasangan penyearah.

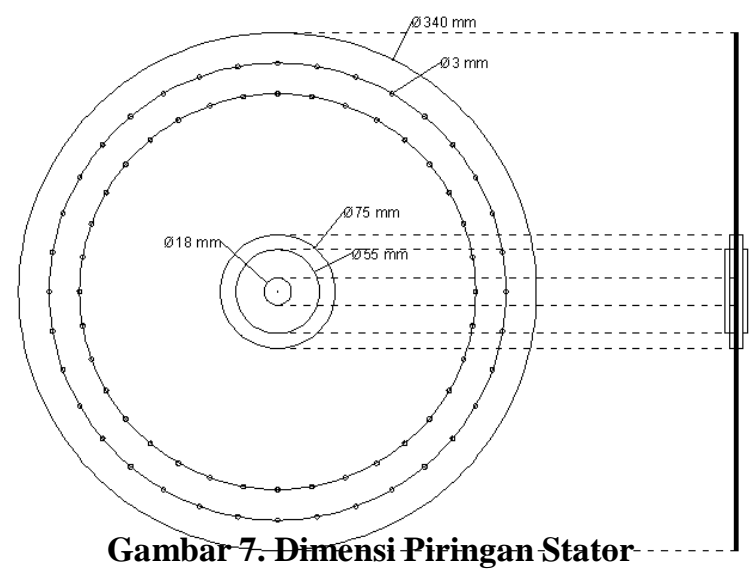

Tabel 6. Spesifikasi Komponen Piringan Stator

\begin{tabular}{l|l} 
Parameter & Besaran (mm) \\
\hline Diameter piringan stator & $340 \mathrm{~mm}$ \\
Lubang penempatan poros & $18 \mathrm{~mm}$ \\
Lubang pengait kumparan & $3 \mathrm{~mm}$
\end{tabular}

Komponen stator tersusun atas kawat email tembaga dengan diameter $3 \mathrm{~mm}$. Sebuah kumparan

\subsection{Pembuatan Komponen Motor Impuls}

Pembuatan motor impuls diawali dengan proses pembuatan kumparan (kumparan medan \& induksi) dan pembuatan komponen elektronik serta komponen pendúkung. tembaga dililit hingga 300 kali. Hubungan antar kumparan disusun secara seri. Jarak celah udara antara komponen rotor (atas \& bawah) dan stator ialah menyesuaiakan dengan ketinggian kumparan yang telah disusun $(70 \mathrm{~mm})$. Total kumparan yang digunakan ialah 36 buah.

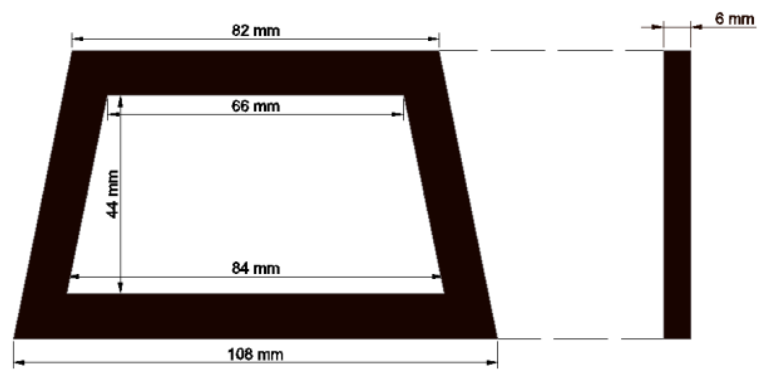

Gambar 8. Bentuk Kumparan Stator
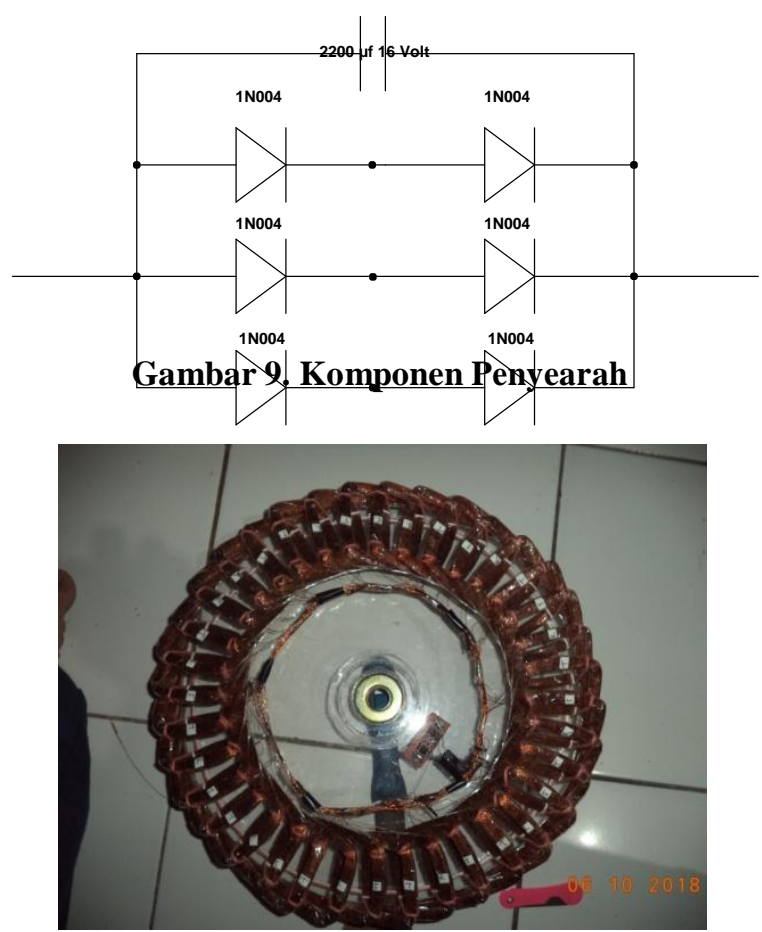

Gambar 10. Bentuk Komponen Stator Akhir 


\subsection{Pembuatan Kotak Pengaman}

Kotak pengaman digunakan sebagai tempat

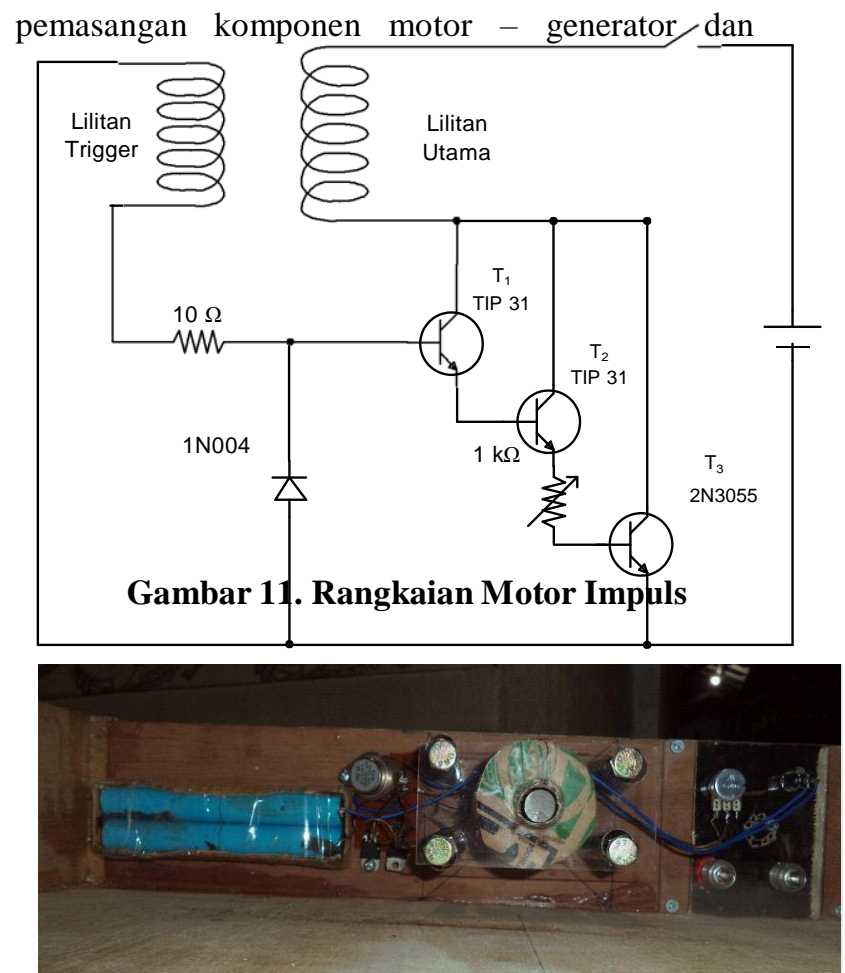

Gambar 12. Bentuk Motor Impuls Akhir

(Tampak Depan)

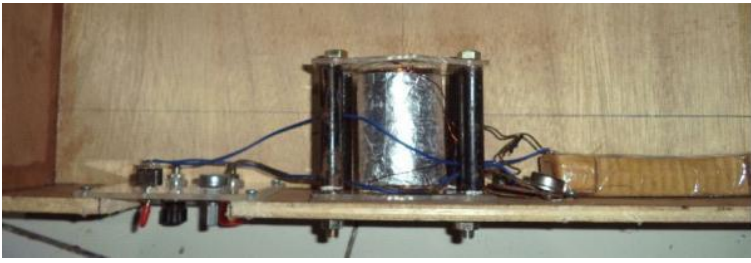

Gambar 13. Bentuk Motor Impuls Akhir (Tampak Atas) berfungsi melindungi komponen dari gangguan eksternal. Bahan pembuatan komponen ini menggunakan papan triplek dengan ketebalan $9 \mathrm{~mm}$.

Gambar 14. Bentuk Kotak Pengaman

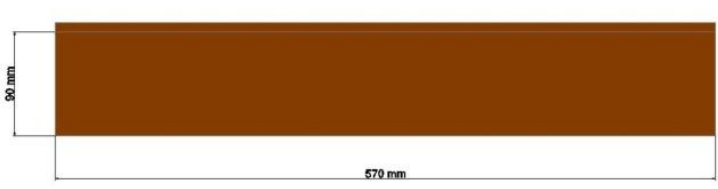

Gambar 15. Bentuk Kotak Pengaman Depan

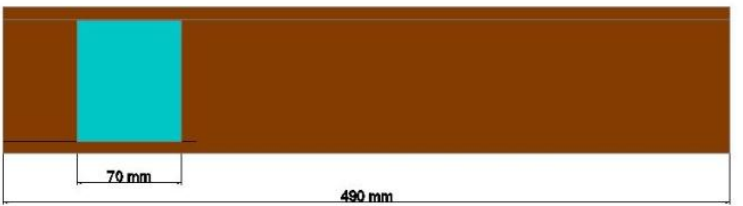

Gambar 16. Bentuk Kotak Pengaman Samping

Tabel 7. Spesifikasi Komponen Kotak Pengaman

\begin{tabular}{l|l} 
Parameter & Besaran $(\mathbf{m m})$ \\
\hline Tutup Kotak Pengaman & $550 \times 570 \mathrm{~mm}$ \\
Alas Kotak Pengaman & $550 \times 570 \mathrm{~mm}$
\end{tabular}


Lubang pengait kumparan

Dimensi Kotak Pengaman Depan

Dimensi Kotak Pengaman Samping

Dimensi Papan Sebagai Terminal

Keluaran Generator

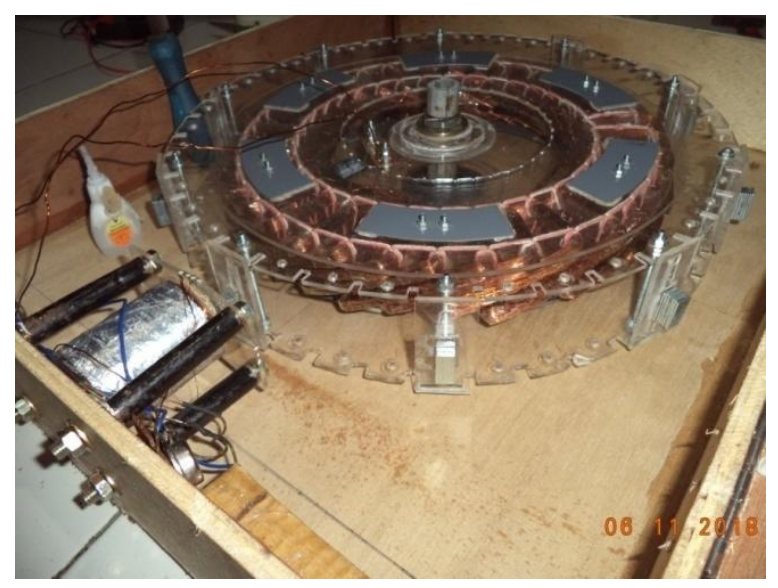

Gambar 17. Bentuk Komponen Ketik Sudah

Terpasang

\section{HASIL \& PEMBAHASAN}

Tabel 8. Data pengujian menggunakan led

\begin{tabular}{|c|c|c|c|c|}
\hline \multirow{2}{*}{ No } & \multirow{2}{*}{ Jumlah } & Tegangan & Arus & Putaran \\
\cline { 3 - 5 } & LED & Volt & mA & rpm \\
\hline 1 & 0 & 9.4 & 0 & 95.24 \\
\hline 2 & 1 & 3 & 7.95 & 86.95 \\
\hline 3 & 2 & 2.85 & 8.08 & 80 \\
\hline 4 & 3 & 2.82 & 8.19 & 80 \\
\hline 5 & 4 & 2.82 & 8.28 & 76.92 \\
\hline 6 & 5 & 2.8 & 8.27 & 84.5 \\
\hline 7 & 6 & 2.8 & 8.26 & 80 \\
\hline 8 & 7 & 2.8 & 8.26 & 83.33 \\
\hline 9 & 8 & 2.8 & 8.27 & 79.97 \\
\hline 10 & 9 & 2.8 & 8.26 & 76.92 \\
\hline 11 & 10 & 2.8 & 8.31 & 76.87 \\
\hline 12 & 11 & 2.8 & 8.36 & 79.98 \\
\hline
\end{tabular}

Tabel 9 Data pengujian menggunakan resistor susun seri

\begin{tabular}{|c|c|c|c|}
\hline \multirow{2}{*}{ No } & Tahanan & Tegangan & Arus \\
\cline { 2 - 4 } & Ohm & Volt & mA \\
\hline 1 & 3.9 & 0.18 & 12.22 \\
\hline 2 & 6.8 & 0.21 & 12.18 \\
\hline 3 & 8 & 0.23 & 12.17 \\
\hline
\end{tabular}

\begin{tabular}{|c|c|c|c|}
\hline 4 & 16.2 & 0.332 & 12.07 \\
\hline 5 & 2.8 & 0.164 & 12.28 \\
\hline 6 & 8.3 & 0.232 & 12.16 \\
\hline 7 & 9.5 & 0.24 & 12.14 \\
\hline 8 & 17.7 & 0.348 & 12.04 \\
\hline 9 & 5.7 & 0.2 & 12.17 \\
\hline 10 & 6.8 & 0.215 & 12.18 \\
\hline 11 & 12.4 & 0.283 & 12.12 \\
\hline 12 & 20.6 & 0.382 & 11.99 \\
\hline 13 & 6.9 & 0.213 & 12.25 \\
\hline 14 & 21.8 & 0.394 & 11.91 \\
\hline 15 & 15.1 & 0.313 & 12.02 \\
\hline
\end{tabular}

Tabel 10 Data pengujian menggunakan resistor susun paralel

\begin{tabular}{|c|c|c|c|}
\hline \multirow{2}{*}{ No } & Tahanan & Tegangan & Arus \\
\cline { 2 - 4 } & Ohm & Volt & mA \\
\hline 1 & 0.099 & 0.13 & 12.26 \\
\hline 2 & 0.83 & 0.141 & 12.30 \\
\hline 3 & 0.988 & 0.143 & 12.36 \\
\hline 4 & 1.02 & 0.145 & 12.38 \\
\hline 5 & 1.11 & 0.146 & 12.41 \\
\hline 6 & 0.096 & 0.138 & 12.48 \\
\hline 7 & 1.82 & 0.154 & 12.48 \\
\hline 8 & 1.933 & 0.167 & 12.47 \\
\hline 9 & 2.288 & 0.163 & 12.50 \\
\hline 10 & 0.098 & 0.137 & 12.53 \\
\hline 11 & 0.988 & 0.15 & 12.52 \\
\hline 12 & 3.071 & 0.17 & 12.47 \\
\hline 13 & 4.078 & 0.18 & 12.48 \\
\hline 14 & 0.099 & 0.134 & 12.24 \\
\hline 15 & 4.679 & 0.185 & 12.18 \\
\hline
\end{tabular}

Tabel 11. Data pengujian menggunakan potensiometer (Daya Masukan Motor)

\begin{tabular}{|c|c|c|c|}
\hline \multirow{2}{*}{ No } & \multicolumn{3}{|c|}{ Input } \\
\cline { 2 - 4 } & $\mathbf{V}$ & I & P \\
\hline 1 & 18.8 & 0.82 & 15.51 \\
\hline 2 & 18.82 & 0.82 & 15.53 \\
\hline 3 & 18.84 & 0.77 & 14.60 \\
\hline 4 & 18.84 & 0.78 & 14.79 \\
\hline 5 & 18.85 & 0.77 & 14.61 \\
\hline 6 & 18.82 & 0.74 & 14.03 \\
\hline 7 & 18.85 & 0.76 & 14.33 \\
\hline
\end{tabular}




\begin{tabular}{|c|c|c|c|}
\hline 8 & 18.84 & 0.75 & 14.13 \\
\hline 9 & 18.84 & 0.74 & 13.95 \\
\hline 10 & 18.84 & 0.78 & 14.70 \\
\hline 11 & 18.35 & 0.82 & 15.05 \\
\hline 12 & 18.36 & 0.88 & 16.16 \\
\hline 13 & 18.33 & 0.88 & 16.13 \\
\hline 14 & 18.33 & 0.9 & 16.50 \\
\hline 15 & 18.34 & 0.88 & 16.14 \\
\hline 16 & 18.34 & 0.88 & 16.14 \\
\hline 17 & 18.31 & 0.94 & 17.21 \\
\hline 18 & 18.34 & 0.95 & 17.42 \\
\hline 19 & 18.34 & 0.95 & 17.42 \\
\hline 20 & 18.22 & 1.01 & 18.40 \\
\hline 21 & 18.27 & 0.995 & 18.18 \\
\hline 22 & 18.98 & 0.96 & 18.22 \\
\hline 23 & 19.005 & 0.98 & 18.63 \\
\hline 24 & 19.01 & 0.92 & 17.49 \\
\hline 25 & 19.005 & 0.925 & 17.58 \\
\hline 26 & 19.005 & 0.91 & 17.30 \\
\hline 27 & 19.005 & 0.915 & 17.39 \\
\hline 28 & 19.02 & 0.91 & 17.31 \\
\hline 29 & 19.005 & 0.9 & 17.11 \\
\hline 30 & 19.03 & 0.895 & 17.03 \\
\hline 31 & 18.99 & 0.965 & 18.33 \\
\hline 32 & 18.995 & 0.93 & 17.67 \\
\hline 33 & 19.005 & 0.94 & 17.87 \\
\hline 34 & 19.01 & 0.905 & 17.20 \\
\hline 35 & 19.005 & 0.88 & 16.72 \\
\hline 36 & 19.01 & 0.885 & 16.82 \\
\hline 37 & 19.015 & 0.88 & 16.73 \\
\hline 38 & 19.025 & 0.875 & 16.65 \\
\hline 39 & 19.02 & 0.87 & 16.55 \\
\hline 40 & 19.005 & 0.905 & 17.20 \\
\hline 41 & 19.01 & 0.875 & 16.63 \\
\hline
\end{tabular}

Tabel 12. Data pengujian menggunakan potensiometer (Daya Keluaran Generator)

\begin{tabular}{|c|c|c|c|c|c|}
\hline \multirow[t]{3}{*}{ No. } & \multicolumn{3}{|c|}{ Output } & \multirow[b]{2}{*}{ Tahanan } & \multirow[b]{2}{*}{ Efisiensi } \\
\hline & $\mathbf{V}$ & I & $\mathbf{P}$ & & \\
\hline & (V) & $(\mathbf{m A})$ & (Watt) & (Ohm) & $(\%)$ \\
\hline 1 & 0.26 & 0.013 & 0.003 & 10 & 0.021 \\
\hline 2 & 0.31 & 0.013 & 0.004 & 15 & 0.025 \\
\hline 3 & 0.36 & 0.013 & 0.005 & 18 & 0.031 \\
\hline 4 & 0.39 & 0.013 & 0.005 & 20 & 0.033 \\
\hline 5 & 0.41 & 0.013 & 0.005 & 22 & 0.035 \\
\hline 6 & 0.52 & 0.013 & 0.007 & 27 & 0.047 \\
\hline 7 & 0.54 & 0.012 & 0.007 & 33 & 0.047 \\
\hline 8 & 0.635 & 0.012 & 0.008 & 39 & 0.056 \\
\hline 9 & 0.935 & 0.013 & 0.012 & 68 & 0.087 \\
\hline 10 & 1.115 & 0.012 & 0.013 & 82 & 0.088 \\
\hline 11 & 1.116 & 0.011 & 0.012 & 95 & 0.079 \\
\hline 12 & 1.18 & 0.01 & 0.012 & 100 & 0.076 \\
\hline 13 & 1.96 & 0.009 & 0.018 & 200 & 0.114 \\
\hline 14 & 2.58 & 0.008 & 0.022 & 300 & 0.131 \\
\hline 15 & 3.2 & 0.008 & 0.024 & 400 & 0.149 \\
\hline 16 & 3.63 & 0.007 & 0.026 & 500 & 0.158 \\
\hline 17 & 4.02 & 0.006 & 0.026 & 600 & 0.152 \\
\hline 18 & 4.33 & 0.005 & 0.022 & 700 & 0.124 \\
\hline 19 & 4.65 & 0.006 & 0.026 & 800 & 0.151 \\
\hline 20 & 4.95 & 0.004 & 0.021 & 900 & 0.116 \\
\hline 21 & 5.19 & 0.005 & 0.026 & 1000 & 0.143 \\
\hline 22 & 4.83 & 0.005 & 0.023 & 1000 & 0.128 \\
\hline 23 & 6.055 & 0.006 & 0.037 & 2000 & 0.197 \\
\hline 24 & 6.945 & 0.007 & 0.048 & 3000 & 0.276 \\
\hline 25 & 7.385 & 0.007 & 0.055 & 4000 & 0.31 \\
\hline 26 & 7.72 & 0.008 & 0.06 & 5000 & 0.345 \\
\hline 27 & 7.91 & 0.008 & 0.063 & 6000 & 0.36 \\
\hline 28 & 8.045 & 0.008 & 0.065 & 7000 & 0.374 \\
\hline 29 & 8.25 & 0.008 & 0.068 & 8000 & 0.398 \\
\hline
\end{tabular}




\begin{tabular}{|l|c|c|c|c|c|}
\hline 30 & 8.345 & 0.008 & 0.070 & 9000 & 0.409 \\
\hline 31 & 8.195 & 0.008 & 0.067 & 10000 & 0.366 \\
\hline 32 & 8.31 & 0.008 & 0.069 & 11000 & 0.391 \\
\hline 33 & 8.46 & 0.008 & 0.072 & 12000 & 0.401 \\
\hline 34 & 8.52 & 0.009 & 0.073 & 13000 & 0.422 \\
\hline 35 & 8.505 & 0.009 & 0.072 & 14000 & 0.433 \\
\hline 36 & 8.51 & 0.009 & 0.072 & 15000 & 0.430 \\
\hline 37 & 8.535 & 0.009 & 0.073 & 16000 & 0.435 \\
\hline 38 & 8.555 & 0.009 & 0.073 & 17000 & 0.440 \\
\hline 39 & 8.84 & 0.009 & 0.078 & 18000 & 0.472 \\
\hline 40 & 8.62 & 0.009 & 0.074 & 19000 & 0.432 \\
\hline 41 & 8.78 & 0.009 & 0.077 & 20000 & 0.463 \\
\hline
\end{tabular}

$$
\begin{aligned}
\text { Efisiensi } & =\frac{\text { Daya Keluaran }}{\text { Daya Masukan }} \cdot 100 \% \\
& =\frac{0.077}{16.63} \cdot 100 \% \\
& =0.463 \%
\end{aligned}
$$

Pengujian generator menggunakan variasi jumlah led, variasi nilai resistor (susun seri dan paralel) dan variasi nilai potensiometer. Pada penggunaan variasi jumlah led dan variasi nilai resistor tidak menimbulkan kenaikan arus yang signifikan sehingga penggunaan beban digantikan oleh potensiometer. Skala penggunaan nilai potensiometer dengan rentang nilai antara $10-20$ $\mathrm{KOhm}$.

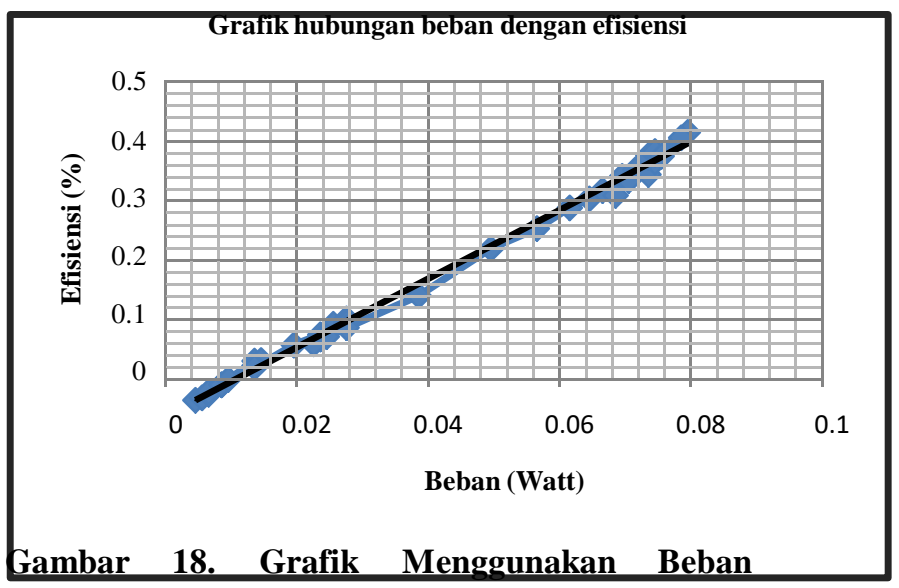

\section{Potensiometer}

Pada gambar 18, digambarkan hubungan antara kenaikan beban yang digunakan dengan nilai efisiensi prototipe. Berdasarkan grafik, ketika generator diberi kenaikan nilai beban menghasilkan kecenderungan kenaikan nilai efisiensi.l

$$
\begin{aligned}
& =8.78 \cdot 0.009 \\
& =0.077 \text { Watt }
\end{aligned}
$$




\section{KESIMPULAN}

1. Prototipe motor - generator fluks aksial magnet permanen jenis $\mathrm{NdFeB}$ dapat menghasilkan listrik dengan daya rendah.

2. Pengujian generator menggunakan beban berupa led, resistor dan potensiometer. Jenis beban yang dapat dianalisa berasal dari beban potensiometer karena memiliki kesesuaian hubungan antara nilai tahanan, tegangan dan arus serta memiliki rentang nilai tahanan yang besar.

3. Data hasil pengujian generator tertinggi pada penggunaan beban $18 \mathrm{KOhm}$ menghasilkan daya sebesar 0.078 watt dengan nilai efisiensi $0.472 \%$.

\section{DAFTAR PUSTAKA}

Alfarisi, Azzmi dan Indra Yasri.2016. “Aspek Perancangan Generator Magnet Permanen Fluks

Aksial 1 Fasa Untuk Mengakomodir Kecepatan

Putar 500-600 RPM'.Jurnal FTEKNIK, Volume 3, No. 2, Pekan Baru. Universitas Riau (Jurnal)

Fitzgerald, A.E dkk. 1997. Mesin - Mesin Listrik Edisi Keempat. Jakarta: Erlangga

Fitzgerald, A.E dkk. 1981. Mesin - Mesin Listrik Edisi Kelima. Jakarta: Erlangga

Gieras, Jacek F, 2008, "Permanent Magnet Motor Technology Third Edition Design And Application", New York: CRC Press (Ebook)

Indriani, Amizar.2015. "Analisis Pengaruh Variasi Jumlah Kutub dan Jarak Celah Magnet Rotor Terhadap Performan Generator Sinkron Fluks Radial". Jurnal Rekayasa dan Teknologi Elektro,
Volume 9, No. 2, Bengkulu: Universitas Bengkulu (Jurnal)

Judge, Andy.2012. Dissertation : “Air Gap Elimination in Permanent Magnets Machines". Worcester: Worcester Polytechnic Institute (Disertasi)

Mahmoudi, A, N.A. Rahim dan H. W. Ping.2012. "Axial Flux Permanent Magnet Motor Design For Electric Vehicle Direct Drive Using Sizing Equation And Finite Element Analysis".Progress In Electromagnetics Research, Volume 122, No.467 496, Kuala Lumpur: University of Malaya (Jurnal)

Ni'matullah, Ginanjar. 2018. Analisis Kuat Medan Magnet, Rpm dan Arus Bedini Ssg Pada Perubahan Jumlah Lilitan dan Variasi Beban. Jember: Universitas Jember (Skripsi)

Nugroho, Wahyudianto Bagus, Indra Ranu Kusuma dan Sardono Sarwitto. 2014. "Kajian Teknis Gejala Magnetisasi pada Linear Generator untuk Alternatif Pembangkit Listrik". Jurnal Teknik Pomits, Volume 3, No. 1, Surabaya: Institut Teknologi Sepuluh November (Jurnal)

Rijono, Yon. 2004. Dasar Teknik Tenaga Listrik. Yogyakarta: Andi Publisher

S, Derito Nanda, Miftahul Munir. 2011. "Pembuatan Motor Magnet Dengan Memanfaatkan Energi Pada Magnet Permanen Sebagai Penggeraknya". Surabaya: Institut Teknologi Sepuluh November (Jurnal)

Sofian, Edy. 2011. Studi Bentuk Rotor Magnet

Permanen Pada Generator Sinkron Magnet Permanen Fluks Aksial Tanpa Inti Stator. Jakarta: Universitas Indonesia (Skripsi) 